Iryna Antonyuk,

Candidate of Engineering Sciences, Associate Professor of the Department of Technology and Organization of Restaurant Industry Kyiv National University of Trade Economics 19, Kyoto str., Kyiv, 02156, Ukraine ORCID: 0000-0003-4629-3403 ResearcherID: N-4736-2016 Anzhelika Medvedieva, Candidate of Engineering Sciences, Associate Professor of the Department of Technology and Organization of Restaurant Industry Kyiv National University of Trade Economics 19, Kyoto str., Kyiv, 02156, Ukraine ORCID: 0000-0002-7991-9161

ResearcherID: N-4738-2016

\title{
TECHNOLOGY OF PUMPKIN SAMBUK «GOLDEN STAR» WITH THE USE OF CYSTOSEIRA
}

The article deals with the technology of pumpkin sambuk with Cystoseira, and comparative characterization of the chemical composition of traditional and prototypes. It was proved that the use of technology of pumpkin sambuk with Cystoseira increases Iodine and Selenium levels in the product and improves the nutritional value of it.

Keywords: sambuk desserts, pumpkin, Cystoseira, microelementosis.

Relevance of the research topic. The structure of the diet of the population of Ukraine has a number of shortcomings: deficiency of animal proteins, PUFA (on the background of excess of animal proteins), pronounced deficiency of most vitamins, microelements, including Ferum, iodine (important for pregnant women and children), Selenium and Zinc [1]. Therefore, providing the population of Ukraine with proper nutrition is one of the most pressing problems today. 
Formulation of the problem. Iodine deficiency is directly related to nutrition, with insufficient iodine content and protein. At the same time, the problem of »endemic areas» over the last decades, irrational agricultural activity has led to an intense washout of iodine and other soluble microelements from the soil of most of the territory of Ukraine $[2 ; 3]$.

Today, it is known that the use of artificial Iodine compounds does not provide the human body with this important micronutrient, since there is a difference in the metabolism of organic and inorganic Iodine. That is why attention should be paid to those substances that contain Iodine in a bioavailable form for the human body, in particular seaweed [4].

Analysis of recent research and publications. Today, scientists around the world are working on creating functional foods, with particular interest being given to products in high demand and technologically not too expensive.

Food enrichment is a serious interference in the traditionally formed structure of human nutrition, the necessity of which is dictated by objective changes in the way of life, the set and the nutritional value of the used foods. Therefore, the enrichment should be based only on clearly formulated, scientifically substantiated and practicetested biomedical and technological principles [5].

The issue of creating new types of sweet dishes is of particular importance today. The problem of developing new types of sweet dishes is addressed by a large number of scientists. Thus Levkun K., Poliovyk V. proposed new types of structureforming agents for the dessert production [6], Kalakura M. and Shchirska O. - the use of apiproducts [7], Mgebryshvili I. proposed the use of concentrate cultures in the recipe of multicomponent milk dessert [8], Radionova L. and Dudyi S. - the use of plant material in the technology of desserts [9], and Belozerova M. Suggested the technology of milk dessert with carrot fiber [10].

Presenting main material. The aim of scientific research is the study and development of new technologies of desserts of high biological value, in particular the sambuk «Golden Star».

Object of research: technology of the pumpkin sambuk «Golden star» with Cystoseira.

Subject of study: Cystoseira powder according to TU U 21663408. 001-2006 (manufactured by EkoMedProdukt LLC), obtained by low-temperature drying; pumpkin sambuk.

As a control sample pumpkin sambuk was used, made according to traditional technology. 
Research methods: organoleptic, physicochemical, mathematical data processing and using computer technologies.

The mineral content was determined by the atomic absorption method on a spectrophotometer Techtron-AA-4 (Austria), and Iodine by the method of inverse voltammetry (device AVA-3, Russia) [11].

Sambuk is a dessert made from fruit or vegetable puree, whipped egg whites, sugar, gelatin, and then chilled. Sometimes small pieces of fruit and berries are added to the puree.

The main ingredient of pumpkin sambuk is pumpkin. Pumpkin is a tasty and healthy vegetable that contains a lot of carotene and vitamins. Cellulose in this vegetable is easily absorbed even by a weakened organism, so pumpkin dishes are recommended for therapeutic and preventive nutrition. Pumpkin is an excellent regulator of digestion and thanks to the high pectin level promotes the removal of cholesterol from the organism. Of organic acids, pumpkin contains mainly malic acid. [12].

A term «food water-plants» has existed over thirty years. During this time, alga products were used as fillers, thickeners, stabilizers, gelling additives. Polysaccharides that are part of the algae stimulate the secretory-motor function of the intestine, promote the elimination of toxic substances from the body. They are used to prevent many diseases of the gastrointestinal tract, diabetes, cholelithiasis, peptic ulcer [4].

In the seas of Ukraine there are large reserves of brown algae - Cystoseira. The results of chemical analysis show us that $1 \mathrm{~g}$ (dry matter) provides the daily requirement for Iodine, Manganese, Selenium and Cobalt. Its chemical content (mg per 100 g): Iodine (75-175), Selenium (65-95), Ferum (15-30), cobalt (3. 3-3. 5) and other microelements rank Cystoseira in these indicators in the first place among Ukrainian food products. In addition, it contains different polysaccharides - alginic acid, fucoidin, iodine-containing amino acids and vitamins [4].

Adding algae to the recipes (незвичний для англійської мови вираз) of different dishes and products allows us to meet the demand for iodine-containing compounds and a number of other biologically active substances and compensate for their lack better, expanding the range of food products.

The mineral composition of the test products is shown in Table 1 . 
Mineral composition of Cystoseira and pumpkin, (mg per 100g of product)

\begin{tabular}{|l|c|c|}
\hline \multicolumn{1}{|c|}{ Indicators } & Cystoseira & Pumpkin \\
\hline Calcium & 354 & 25,0 \\
\hline Potassium & 1006 & 204,0 \\
\hline Magnesium & 875 & 14,0 \\
\hline Iron & 7,65 & 0,4 \\
\hline Iodine & 25 & 0,001 \\
\hline Selenium & 4 & - \\
\hline
\end{tabular}

The content of many chemical elements of Cystoseira significantly exceeds terrestrial plants. The amount of Iodine in the Cystoseira is much greater than in the terrestrial flora. Minerals, mainly (75-85\%), are represented by water-soluble salts of potassium and sodium (chlorides, sulfates).

The general technological scheme of production of the Gold Star sambuk consists of the following operations: preparation of raw materials, whipping mashed potatoes, mixing of ingredients, cooling, quality control.

In order to optimize the recipe of the sambuk and enrich it with iodine, the technology of the «Golden Star» sambuk with Cystoseira was developed (Fig. 1).

Organoleptic indicators play a decisive role in the study of the quality of prepared dishes, as they allow us to more fully evaluate the quality of the restaurant industry. When performing an organoleptic evaluation of pumpkin sambuk, five important interrelated indicators were examined: appearance, color, texture, smell and taste. For the study of organoleptic indicators, we used a five-point system, taking into account the weighting factors that were determined for each indicator.

The highest weight ratio is assigned to the «taste» indicator because it is the taste that forms the main consumer characteristics of the products. Taste is a complex impression that exerts a great, and in most cases decisive, influence on the quality of dishes.

As a result of experimental studies with the addition of Cystoseira in different quantities (experiment $1-0.5 \%$ of dry Cystoseira; experiment 2-0.7\% of dry Cystoseira; experiment $3-0.9 \%$ of dry Cystoseira from the finished dish) by organoleptic evaluation, the rational concentration in the pumpkin sambuk «Golden Star» was found, and it is $0.7 \%$ of dry Cystoseira by weight of dessert. 


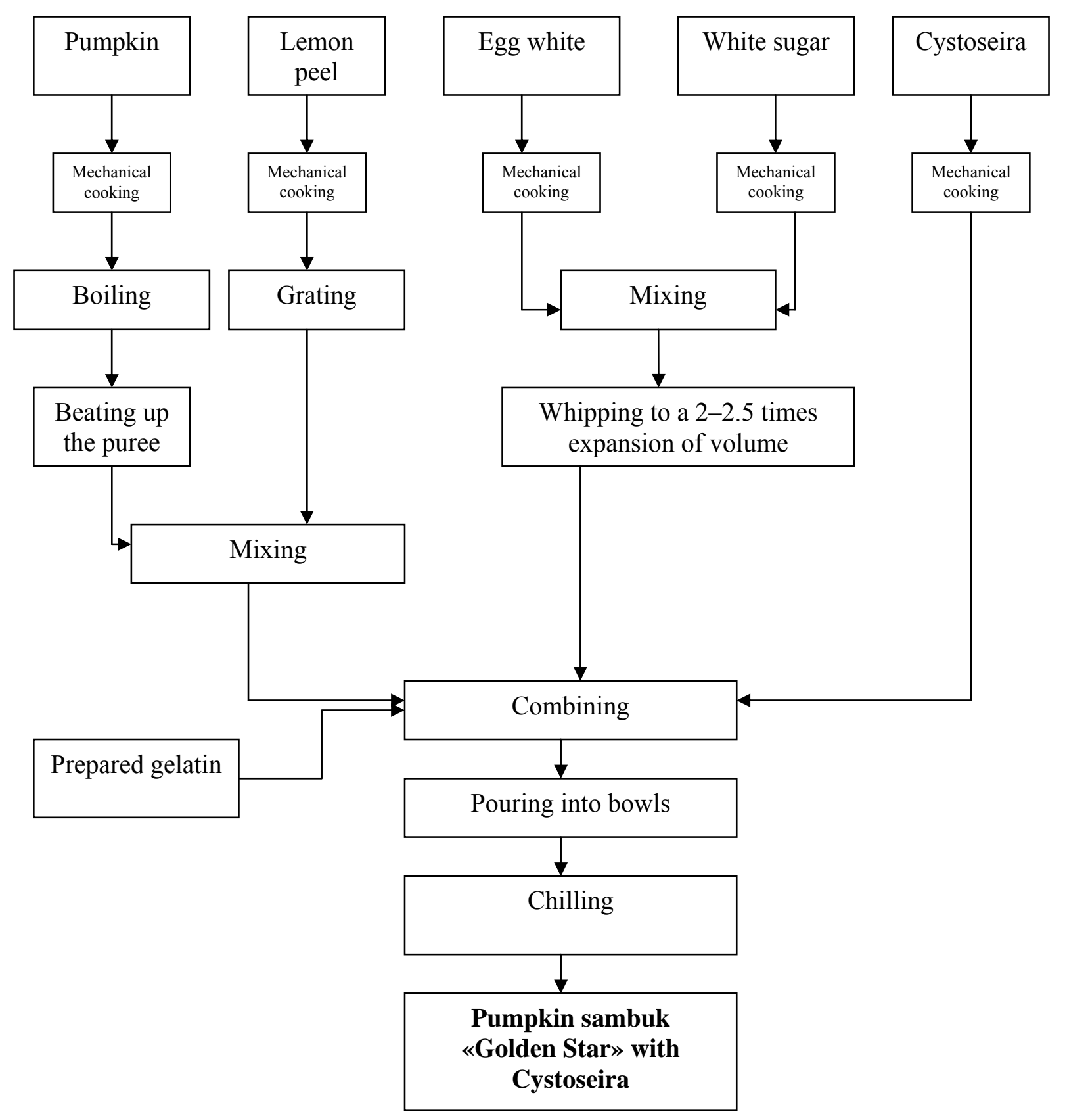

Figure 1. Flow chart of production of the pumpkin sambuk "Golden Star» with Cystosyira

The choice of this quantity of additive is explained by the need to set a limit for its maximum and minimum use in order to preserve all organoleptic characteristics of desserts. Since the standard yield of a portion of dessert is $150 \mathrm{~g}$, the amount of Cystoseira is accordingly $-1 \mathrm{~g}$. The following studies were conducted to yield a standard portion of $150 \mathrm{~g}$. 
The chemical composition and comparative analysis of the samples are shown in table 2.

Table 2

\section{Chemical composition of the control and test samples of pumpkin sambuk «Golden Star» with Cystoseira, 150 g}

\begin{tabular}{|l|c|c|c|}
\hline \multicolumn{1}{|c|}{ Indicators } & Control & Test sample & Difference, $\%$ \\
\hline Potassium, mg & $219.0 \pm 10.0$ & $256.0 \pm 10.0$ & 16.9 \\
\hline Calcium, mg & $26.0 \pm 1.0$ & $86.0 \pm 4.0$ & 3.3 times \\
\hline Magnesium, $\mathrm{mg}$ & $15.0 \pm 1.0$ & $22.0 \pm 1.0$ & 46.7 \\
\hline Phosphorus, $\mathrm{mg}$ & $28.0 \pm 1.0$ & $30.0 \pm 1.0$ & 7.1 \\
\hline Zinc, $\mathrm{mkg}$ & $263.0 \pm 10$ & $269.0 \pm 10$ & 2.3 \\
\hline Iron, mkg & $415.0 \pm 20.0$ & $612.0 \pm 20.0$ & 47.5 \\
\hline Iodine, $\mathrm{mkg}$ & $1.70 \pm 0.008$ & $95.0 \pm 4.0$ & 55.9 times \\
\hline Selenium, $\mathrm{mkg}$ & $2.30 \pm 0.1$ & $47.0 \pm 2.0$ & 20.4 times \\
\hline
\end{tabular}

Analyzing the main indicators of chemical composition, we observe an increase of Calcium content - 3.3 times, Magnesium - 46.7 \%, Iodine - 55. 9 times, Selenium 20.4 times.

Research was conducted to ensure the daily requirement for basic minerals developed by dessert (Table 3 ).

Table 3

\section{Provision of daily needs of minerals when consumed the pumpkin sambuk «Golden Star» (150g) [13]}

\begin{tabular}{|l|c|c|c|}
\hline \multicolumn{1}{|c|}{ Indicators } & $\begin{array}{c}\text { Daily requirement, } \\
\mathrm{mg}\end{array}$ & Control, $\%$ & Test sample, \% \\
\hline Potassium & 3000 & 7.3 & 8.5 \\
\hline Calcium & 1000 & 2.6 & 8.6 \\
\hline Magnesium & 400 & 3.4 & 5.5 \\
\hline Phosphorus & 1200 & 2.3 & 2.5 \\
\hline Zinc & 15 & 1.75 & 1.8 \\
\hline Iron & 15 & 2.8 & 4.1 \\
\hline Iodine & 0.15 & 1.13 & 63.3 \\
\hline Selenium & 0.07 & 3.3 & 67.1 \\
\hline
\end{tabular}

*The daily requirement is specified for men. 
According to certain indicators, a profile of the mineral composition of the «Golden Star» sambuk was constructed using Cystoseira using the EXCEL 97 WINDOWS package (Fig. 2).
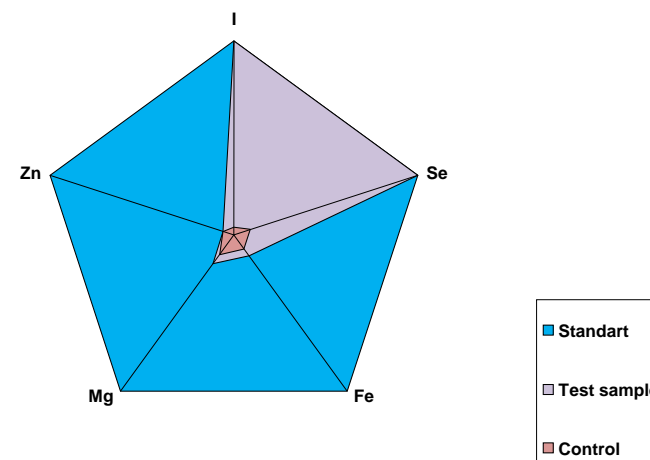

Figure 2. The profile of the mineral composition of the pumpkin sambuk «Golden Star»

The form of the above profile is in the form of a pentagon, the vertices of which are determined by the mineral substances of the studied dish, which are taken for $30 \%$ of meeting the daily needs of the population. The quality profiles of the developed dish have a larger surface area compared to the control sample, and in terms of Iodine and Selenium content exceed the standard because they satisfy the daily requirement for these substances by 63.3 and $67.1 \%$ respectively [14].

Conclusions: Thus, the further development of the restaurant industry is connected with the need to use and implement modern methods of processing raw materials to produce high-quality food products, with the purpose of creating on their basis products intended for consumption, which will reduce the negative environmental effects on the human body.

Therefore, having carried out the research, a comparative characteristic of the quality of a dish, it can be noted that it will to some extent contribute to overcoming the deficiency in the diet of very important minerals for our body, especially iodine and selenium.

It would be advisable to introduce the developed dessert in the menu of restaurants - this would help improve the health and well-being of consumers.

\section{REFERENCES}

1. The causes of changes in the nutritional structure of modern man. Health and body: helpful tips. Access mode: http://opportunity. com. ua/teoriya/prichinyizmenenij-v-strukture-pitaniya-sovremennogo-cheloveka. html

2. Andreichuk V. P. Organic Iodine and human nutrition / V. P. Andreichuk, L. V. Dracheva // Food. industry, 2004, No. 10. - P. 90-92. 
3. Mamenko M. Irrational nutrition as a prerequisite for the formation of iodine and iron deficiency in children / M. Mamenko // Perinatology and pediatrics. - 2008. № 3 (35). - P. 86-90.

4. Korzun V. N., Vorontsova T. O. ; Antonyuk I. Yu. Ecology and diseases of the thyroid gland: monograph: 2nd edition, supplement. and recycling. For the title. ed. MD, Professor VN Korzun. Kyiv: Chair, 2020. 740 p.

5. Rudavska G. B, Tyshchenko E. V, Prytulska N. V Scientific approaches and practical aspects of optimization of the range of special purpose products: Monograph. K. : Kyiv. nat. trading econ. univ. 2002. $-371 \mathrm{p}$.

6. Levkun K. Y, Poliovyk V. V, Bondar N. P, Koretska I. L Research on the structure of new desserts / Young Scientist // № 6 (46) June 2017. - P. 359-363.

7. Kalakura M. M, Shchyrska OV New technologies of dessert products with apiproducts // Odessa National Academy of Food Technologies - Scientific works; Volume 46, Volume 1-pp. 183-187.

8. Mgebrishvili I. V., Seluneva E. A., Korotkova A. A., Gorlov I. F. The effectiveness of the use of melon concentrates in the formulation of a multicomponent milk dessert // Storage and processing of agricultural raw materials // No. 8, 2013 P. 44-45.

9. Rodionova L. Ya., Dudyi S. A. Development of a plant dessert for functional purposes // Young Scientist. - 2015. - No. 23. - P. 425-428.

10. Belozerova M. S., Evstigneeva T. M., Grigoryeva A. A. Development of the composition and technology of a milk dessert with carrot fiber // Bulletin of the Voronezh State University. - 2016. - No 2. - P. 140-147.

11. Tomcik P. Voltammetric determination of iodide by use of an investigated microelectrode array / P. Tomcik, D. Bustin // Fresenius J. Anal. Chem. - 2001. Vol. 371. - P. 362-364.

12. Useful and healing properties of pumpkin for health. Access mode: http://opolze. net/svoistva/ovoshhi/tykva. $h$ tml

13. Order of the Ministry of Health of Ukraine № 03. 09. 2017. № 1073 On approval of the Norms of physiological needs of the population of Ukraine in basic nutrients and energy. Access mode: https://zakon. rada. gov. ua/laws/show/z1206-17.

14. Mazaraki A. A, Peresichny M. I, Shapoval S. L, Bai S. I, Chayun I. O, Rasulov R. A, Grigorenko O. M, Litvinenko T. E, Antonyuk I. Y., Tarasenko I. I. Design of restaurant facilities: textbook. tool. 2nd ed., Reworked. and additions Kiev: Kiev. nat. trading econ. univ., 2010. 339 p. 